\title{
A critical thinking of Chinese definitions of torture
}

\begin{abstract}
The definition of torture in China is very limited in its legal scope. This situation seems not very important in law, but given that China has signed and ratified the Convention for two decades, it is China's duty to bring the definition of torture in line with international standards. Also, its definition is related to whether or not to exclude all of tortured confessions in China's justice practice. Thus, its legislative revisions on the scope of torture to expand the definition are most needed, in Chinese future institutional reforms on supervising police interrogations and evidence exclusion. This critical thinking from an international human rights perspective could help Chinese courts not to focus on remedying wrongful convictions caused by torture in a narrow sense, but promote them to check and exclude any form of torture from use in conviction or sentencing.
\end{abstract}

Volume 3 Issue I - 2019

\author{
Jiang $\mathrm{Na},{ }^{\prime}$ Han Rong ${ }^{2}$ \\ 'Professor, College for Criminal Law Science, Beijing Normal \\ University (BNU), China \\ ${ }^{2}$ LLM Candidate, Law School of BNU, China
}

Correspondence: Jiang $\mathrm{Na}$, Professor, College for Crimina Law Science, Beijing Normal University (BNU), China, Email na.jiang@bnu.edu.cn

Received: January 04, 2019 | Published: February 25, 2019

Keywords: Chinese definitions of torture, international standards, international impact

\section{Introduction}

One of major differences between Chinese legislation and international standards are related to the definition of torture. In the context of the Convention against Torture (CAT), those committing torture include public officials and others doing so in their official capacity. The scope is clearly much broader than that of definition on torture in China because those committing torture in Chinese legislation are only limited to judicial officials. Also, the current Criminal Law of the PRC $(C L)$ punishes those committing torture in the process of criminal cases only and not the process of civil or administrative cases, whereas torture should apply to any process based on its definition demonstrated in the CAT as a part of international human rights standards. The law does not clarify how to recognize torture in practice. Courts in different districts have taken inconsistent approaches to whether evidence obtained by investigative organs' fatigue tactics or mental torture is unlawful or not. The law will do nothing to clear up the confusion. Moreover, the law is primarily aimed at excluding illegal testimony, while the definition of illegal physical evidence is relatively vague. Judges are given too much discretion over whether to exclude illegal physical evidence. The conditions under which physical evidence should be excluded are too subjective to decrease difficulties in excluding illegally obtained evidence. $^{1}$

The sharp contrast between Chinese definition and international definitions on torture seems to increase the diversity of its definition. But given that China has signed and ratified the Convention for two decades, China should take great efforts to better undertake its international duty in order to fully bring Chinese definition of torture in line with international standards concerned. Also, its legal definition is related to whether to exclude all of confessions collected by means of torture or not in China's justice practice. Thus, expanding the definition of torture in its scope of torture is most needed in Chinese future reforms, i.e., on excluding evidence like tortured confessions. This paper will start from details in Chinese definition of torture, will proceed with the impact of international definitions on torture to China and end with specific reform proposals. ${ }^{2}$

\section{On definitions of torture}

In China, the $1997 C L$ and the 2012 Criminal Procedure Law $(C P L)$ are main statutory rules on the prohibition of torture, apart from their judicial explanations and Evidence Rules. Also, major treaties in international human rights law address (possible) torture or degrading treatment in many aspects. The CAT strictly prohibits any form of torture or degrading punishment by many means as follows: The CAT prohibits torture in a very broad sense, as well as cruel punishment, inhuman or degrading treatment in any form. This is designed to protect the accused from the above punishment or treatment at any stages of the entire criminal process. In fact, PRC has been a party since ratifying the $C A T$ on $3^{\text {rd }}$ November $1988 .{ }^{1}$ Art. 1 of the $C A T$ clarifies that torture should be committed on purpose and not by accident. Also, it defines torture as severe pain or harsh suffering, in a physical or mental form. The act's purposes should be to obtain information or a confession from the tortured and another one concerned, or other reasons like discrimination. The action approaches should include punishing, intimidating and coercing. The nature of torture should be a governmental conduct rather than private acts so that those imposing torture should be public officials or others performing duties. Such requirements constitute a basic concept of torture that State parties need to prohibit. $^{3}$

However, the death penalty itself is not a form of torture at all. It does not satisfy the requirements of torture's definition and also the relevant international human right treaty only prohibits the abuse of the death penalty rather than totally prohibit its use. Thus, the death penalty is not any form of torture under the prohibition of the CAT in principle. The exception to this principle could be the enforcement means or methods of the death penalty that may fall into the category of torture or of inhuman or degrading treatment in a sense of international human rights treaties. For example, shooting should be prohibited as degrading treatment and injection be encouraged as an only method of immediate execution of the death penalty. So, there is no need for State parties to the CAT to abolish the death penalty, but prohibit any forms of torture. ${ }^{4}$

\section{The international impact on China}

As a State party to the $C A T$, China has revised many basic laws in order to bring its criminal law and procedures in line with international standards on the prohibition of torture. In the recent decade, the CPL 2012 and its Amendment have made new changes under the

${ }^{1}$ Second Periodic Reports ofStates Parties Due in 1993: China. 15/02/96, CAT/C/20/Add.5[1] 
influence of international human rights treaties that China ratified. ${ }^{2}$ The CPL 2012 introduces exclusionary rules as a new evidence law. Specifically, Article 50 of the $C P L$ provides that judges, procurators and investigators must collect all kinds of evidence that can prove suspects' or the accused's guilt or innocence in accordance with the legal procedures. It strictly prohibits extorting confessions by means of torture and collecting evidence by means of threats, inducements, deceptions and other illegal methods, and must not force anyone to prove their guilt. Thus, tortured confessions should be excluded from use in order to prohibit torture. ${ }^{5}$

Article 54 of the law further provides for exclusion of criminal suspects' and defendants' confessions collected by illegal methods like extorting confessions by means of torture, and of witness testimonies and victim statements collected by illegal methods such as violence and threats. Physical evidence and documentary evidence, being collected by means against legal procedures so as to seriously affect judicial justice, can also be excluded from use in investigation, review, prosecution or trial. This provision can benefit prohibiting torture from being used in the criminal process. Amendment to the CPL 2012 stipulates the duty counsel system in order to encourage counsel to prohibit torture from being imposed on his or her clients under detention. Accordingly, officials in courts, procuratorates and detention houses have the duty to inform the accused of their right to get access to attorney on duty so that defence counsels' involvement becomes mandatory. If the accused confess, he or she should sign names with a defence lawyer or duty lawyer's presence to prove his or her willingness in confession of guilt, in order to prohibit torture from occurrence again. ${ }^{6}$

\section{Conclusion}

Since its ratification of the $C A T$, China has already modified many domestic laws or rules in order to strictly prohibit any forms of torture by diverse means. But the narrow sense of torture in Chinese definitions has led many of Chinese courts to prohibit torture in a very limited scope in practice. This deviates from the reform direction of expanding torture to a broad scope based on international requirements, and also violates China's due international human rights duties as a State party. Therefore, further legislative revisions on total and full prohibition of torture are most needed, in order to expand its legal scope to the maximum as required by international human rights treaties at the very least, in Chinese future reforms against torture.

\section{Acknowledgments}

None.

\section{Conflicts of interest}

The authors declare that there is no conflict of interest.

\section{References}

1. Ahcene Boulesbaa. The UN Convention on Torture and the Prospects for Enforcement. Boston, Mass, London: Martinus Nijhoff Publishers. 1999:39.

2. William A Schabas. The Abolition of the Death Penalty in International Law. Cambridge, $3^{\text {rd }}$ Edition. 2002:197.

3. UN Doc. E/RES/663C(XXIV)(31/07/1957). UN Doc. E/RES/2076(LXII) $(13 / 05 / 1977)$.

4. Committee against Torture. Second Periodic Reports of States Parties Due in 1993: China. CAT/C/20/Add.5. 1995.

5. Committee against Torture. Third Periodic Reports of States Parties Due in 1997: China. CAT/C/39/Add.2. 2000;1-54.

6. Committee against Torture. Summary Record of the $416^{\text {th }}$ Meeting: China. CAT/C/SR.4f6. 2000.

${ }^{2}$ CAT Report, 1996a at paras. 6 and 7. 